\title{
Fosforilannoituksen optimointi portaittain nousevien P-määrien mukaan
}

\author{
Into Saarela $^{1)}$, Erkki Joki-Tokola ${ }^{2)}$, Arjo Kangas ${ }^{3)}$, Yrjö Salo ${ }^{4)}$, Perttu Virkajärvi ${ }^{5)}$ ja \\ Martti Vuorinen ${ }^{4}$ \\ ${ }^{1)}$ MTT, Maaperä ja kasvinravitsemus,31600 Jokioinen, into.saarela@mtt.fi \\ ${ }^{2)}$ MTT, Maito ja naudanliha, Tutkimusasemantie 15, 92400 Ruukki, erkki.joki-tokola@mtt.fi \\ ${ }^{3)}$ MTT, Kasvintuotanto, Alapääntie 104, 61400 Ylistaro, arjo.kangas@mtt.fi \\ ${ }^{4)}$ MTT, Kasvintuotanto, Toivonlinnantie 518, 21500 Piikkiö, yrjo.salo@mtt.fi \\ ${ }^{5)}$ MTT, Maito ja naudanliha, Halolantie 31 A, 71750 Maaninka, perttu.virkajarvi@mtt.fi \\ ${ }^{4)}$ MTT, Kasvintuotanto, Toivonlinnantie 518, 21500 Piikkiö, martti.vuorinen@mtt.fi
}

\section{Tiivistelmä}

Tutkimusten perusteella suositeltu fosfori- (P) lannoitus on mitoitettu käytännön viljelyä vastaavissa kasvuoloissa tehdyillä, monivuotisilla viljelykokeilla. Kokeissa on verrattu useita portaittain nousevia P-määriä rinnakkaisilla koeruudulla samanlaisissa maaperä ja sääoloissa. Saman aikaan eri paikoissa tai samalla paikalla eri vuosina saadut koetulokset eivät sovellu ravinnemäärien vaikutusten luotettavaan ja tarkkaan mittaamiseen. Usean rinnakkain käytetyn ravinnemäärän ja tavanomaisten neljän kerranteen tuloksista lasketut satovastekäyrät ovat yleensä suhteellisen luotettavia yksittäisissäkin koesadoissa. Tuloksen täsmenevät edelleen koeajan pidentyessä, kun satunnaiset, mm. viljan lakoontuessa suurenevat ruutujen väliset erot eli koevirheet pienenevät useamman vuoden keskiarvoissa. Pitkäaikaisissa viljelykokeissa kasvukauden säästä johtuvat suuret vuotuisvaihtelut tasoittuvat ja kestävässä, taloudellisessa viljelyssä tärkeä toistuvan lannoituksen kumuloituva jälkivaikutus tulee otetuksi huomioon.

Viljavuustutkimusten yleistyttyä 1950-luvulla lannoituksen satovasteet voitiin laskea viljavuusluokittain. Maan P-luvun merkitys ilmeni aluksi parhaiten sokerijuurikkaalla, jonka kasvupaikoista osa oli viljavia jo 1950-luvulla. Melkein kaikissa vilja- ja nurmipelloissa P:sta oli puutetta eikä lannoitustarpeen väheneminen maan P-luvun kasvaessa ollut heti selvästi todettavissa. Maan P-luokassa hyvä P-lannoitus paransi kuitenkin viljan ja nurmen kasvua tuntuvasti vain $\mathrm{pH}: \mathrm{n}$ ollessa arveluttavan korkea tai liian alhainen. P-tilaltaan tyydyttävillä pelloilla lannoitustarve ylitti kasvin ottaman P-määrän selvästi erityisesti happamilla mailla. Vuonna 1991 laaditut ja 1995 tarkennetut lannoitussuositukset perustuivat paljolti vuosina 1977-1994 tehtyihin kenttäkokeisiin, joissa verrattiin viittä vuosittain sijoitettua tai levitettyä P-määrää. Monivuotisten kokeiden pitkän ajan keskiarvot osoittivat maan biologista viljavuutta ja lannoitustarvetta tarkemmin kuin aikaisempien tutkimusten yksivuotiset kokeet. Kivennäismailla alkukesän kuivuus vaikeutti kasvien ravinteiden ottoa ja lisäsi P-lannoituksen vaikutusta satoon.

Nykyiset ympäristötukeen oikeuttavat P-määrät olivat riittäviä keskinkertaista paremmilla mailla tyydyttävän P-luokan yläpäästä alkaen. P-tilaltaan huonommilla mailla tyydyttävän luokan alapää mukaan lukien pitkänä aikana optimaaliset P-määrät olivat tukiehtoja suuremmat ainakin ylijäämälannan P:n ostolannoitteita huomattavasti alemmilla hinnoilla. Tukeen oikeuttavat P-määrät riittivät paremmin Etelä-Suomen hyvärakenteisilla savilla, savisilla hiedoilla ja savisilla multamailla kuin Sisä-Suomessa vallitsevilla karkeilla ja hiesuisilla kivennäismailla, karkeapohjaisilla multamailla ja huonommilla turpeilla. Hyvin niukkafosforisilla mailla tukiehtoja runsaampi P:n käyttö paransi kasvua ja satoja selvästi.

Kasvien P:n saantia voidaan helpottaa ja satoja suurentaa hyvällä maan hoidolla ja oikealla lannoitteen sijoituksella. Happamien kivennäismaiden P-reservejä voidaan hyödyntää kalkituksella. Sijoitetut lannoiterivit tulisi kuivissa oloissa tiivistää. Kosteissa oloissa kuten syysviljoilla ja eloperäisillä mailla lannoite kannattaa sijoittaa melko matalaan. Hyvien viljasatojen tarvitsemat $15-20$ P-kiloa hehtaarille parantavat sadonmuodostukselle kriittistä alkukehitystä paljon tehokkaammin kuin puolta pienempien satojen puolta pienemmät P-määrät.

\section{Asiasanat: lannoitustarve, maan fosforitila, pellon fosforitase, satovastekäyrä}




\section{Johdanto}

Sata vuotta sitten erämaat oli asutettu ja luontaisesti viljavat maat raivattu pelloksi. Kasvavan väestön ruokahuolto edellytti vanhojen viljelysten tuottavuuden parantamista ja vähäravinteistenkin nevojen ja metsämaiden viljelyä lisäravinteiden avulla. Käytännössä maatalouden tehostaminen merkitsi suurten kalkki- ja apulantamäärien levittämistä pelloille melkein jokaiseen kylään perustettujen lannoituskokeiden tuottamien esimerkkien mukaisesti.

Lyhytaikaisia P-lannoituskokeita on tehty 1920-luvulta alkaen sadoilla koepaikoilla. Erikoiskoulutettujen ammattilaisten hoitamia, monivuotisia viljelykokeita, jotka muodostavat luotettavimman perustan lannoitustarpeen määrittämiselle, on tehty tutkimuslaitosten koekentillä useita kymmeniä. Nykyisessä viljelyssä lannoitusta ei voida optimoida aivan erilaisissa viljelyoloissa tehtyjen tutkimusten mukaan, mutta vanhat kokeet kuvaavat maa-kasvi -systeemin toimintaa ja osoittavat, miksi maan P-tilan parantaminen on katsottu välttämättömäksi. Yli sata vuotta on tiedetty, että liukoinen fosfaatti-P pidättyy lujasti maa-ainekseen eikä juuri huuhtoudu vesistöihin.

Lannoituskokeilla määritettyä P:n tarvetta on tutkimuksissa verrattu kemiallisesti analysoituun maan P-tilaan 1930-luvulta alkaen, mutta riippuvuudet olivat aluksi heikkoja (Salonen ja Tainio 1957). Tärkeitä syitä analyysien näennäiseen kehnouteen oli yleisesti huono maan viljavuus ja todella runsasfosforisten vilja- ja heinäpeltojen puuttuminen sekä P-lannoituksen vaikutuksen suuri vuotuisvaihtelu verrattaessa kemiallisia testejä lyhytaikaisiin kenttäkokeisiin (Munk ja Rex 1990). Viljavilla sokerijuurikasmailla kemiallinen testi toimi paremmin jo 1950-luvulla (Brummer 1959).

Saarela ja Sippola (1990) osoittivat happamien maiden kalkituksen sekä pH-luvun käytön selittävänä muuttujana parantavan asetaattimenetelmän tarkkuutta. Maan savespitoisuudella ja muilla ominaisuuksilla on vaikutusta paitsi maalajiryhmien välillä myös niiden sisällä (Saarela ym. 1995, 2006a, 2006b). Karkeiden maiden ongelmana on vesiliukoisen P:n vähyys verrattuna viljavuustutkimuksen P-lukuun, ja hiesuisten maiden ravinteiden saatavuutta heikentää kehno rakenne. Viime vuosina muissa maissa tehdyistä P-lannoituksen optimointihankkeista Munkin (2005) raportoima monivuotinen ja laaja saksalainen kenttäkoesarja on perusteellinen.

Tutkimuksessa tarkastellaan peltokasvien P-lannoituksen tarvetta useiden, samoilla koekentällä rinnakkain käytettyjen P-määrien tuloksista laskettujen satovastekäyrien avulla.

\section{Aineisto ja menetelmät}

P-lannoituksen satovastekäyriä laskettiin eri aikoina tehdyistä kenttäkokeista, joista useimmat ovat olleet lyhytaikaisia (Tennberg 1950, Brummer 1959, Sippola ja Marjanen 1978). Pitkäaikaisia kokeita on tehty 1930-luvulta alkaen eniten turvemailla ja useita myös karkeilla mailla, mutta vähän savimailla (Salonen ja Tainio 1957). Tohmajärven Valkeasuolla polttoturvesuon jättöalueella (Virkajärvi ja Huhta 1992) ja pitkään viljelemättömänä olleella Jokioisten savimaalla niukkafosforisten maiden lannoitus ja viljely vastasivat tavanomaista tekniikkaa. Professori Paavo Elosen johdolla käynnistetty, v. 1977-1994 toteutettu laaja yhteistutkimus Fosforilannoituksen porraskokeet (Saarela ym. 1995, 2006a 2006b), jonka perusteella peltokasvien P-lannoitus on Suomessa paljolti mitoitettu viimeisten 20 vuoden aikana, esitetään lyhyesti mutta aikaisemmin julkaistut tulokset huomioidaan päätelmissä. Oleellinen ero vanhoihin kokeisiin ja Valkeasuon polttoturpeen pohjaan on kymmenien vuosien aikana maahan kertyneet runsaat P-reservit myös liukoisen P:n pitoisuuden ollessa keskinkertainen.

\section{Tulokset ja tarkastelu}

Viljat ja heinä vanhoissa lyhytaikaisissa P-lannoituskokeissa. Eri P-määrillä saatuja, useiden koepaikkojen keskimääräisiä sadonlisäyksiä esitettiin graafisesti jo v. 1950 (Tennberg). Taulukkona esitetyistä tuloksista lasketut satokäyrät esitetään kuvissa 1 ja 2 . Runsaan viiden tonnin heinäsadoissa ja puolta pienemmissä viljasadoissa olkineen, jotka silloin edustivat runsaita satoja, oli fosforia, P, noin $10 \mathrm{~kg} / \mathrm{ha}$. Oletettaessa pienehköjen P-määrien mukaan laskettujen yhtälöiden (Kuva 1) osoittavan suurtenkin vaikutusta, maksimisadon tuottaneet P-määrät voidaan laskea.

Kauran yhtälön derivaatasta, $0,1062 x+13,45$, saadaan käyrän huippua vastaavaksi $\mathrm{P}$-määräksi $13,85 / 0,1062=130 \mathrm{~kg} / \mathrm{ha}$, joka lisäsi satoyhtälön mukaan jyväsatoa $900 \mathrm{~kg} / \mathrm{ha}$ eli seitsenkertaisesti verrattuna nollatasetta vastaavaan 10 kiloon. Keväällä äestäen mullattu P on ollut huonosti saatavilla. Pintalannoitus on erityisen tehotonta orasvaiheessa pinnaltaan nopeasti kuivuvilla ja juurettomilla savimailla. Perunalla satokäyrän loivuus ei johtunut niinkään lannoitusmenetelmästä vaan satoisan mutta heikkojuurisen kasvin vaateliaisuudesta. 


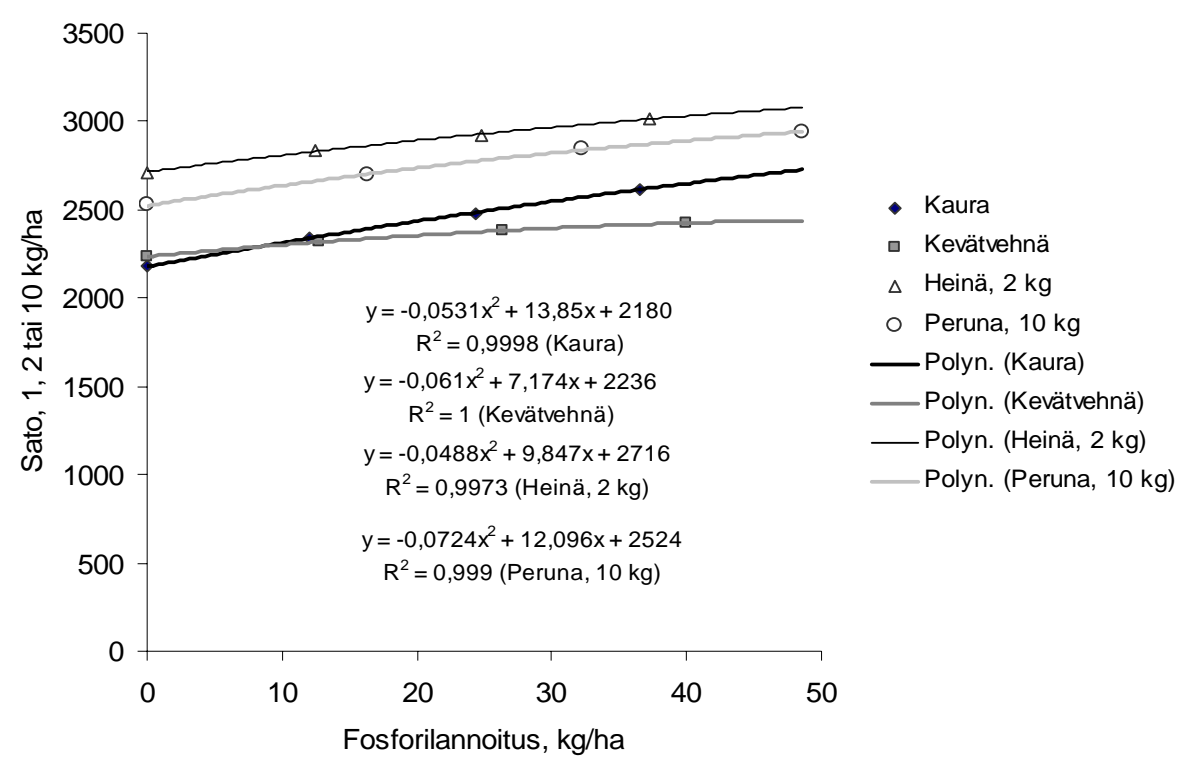

Kuva 1. P-lannoituksen satovasteita kivennäismailla, peruna kaikilla maalajeilla (Tennberg 1950). Koesatoja: heinä 48, kaura 36, kevätvehnä 20, peruna 63, yksikköinä $1 \mathrm{~kg}$ viljaa, $2 \mathrm{~kg}$ heiniä ja $10 \mathrm{~kg}$ perunoita.

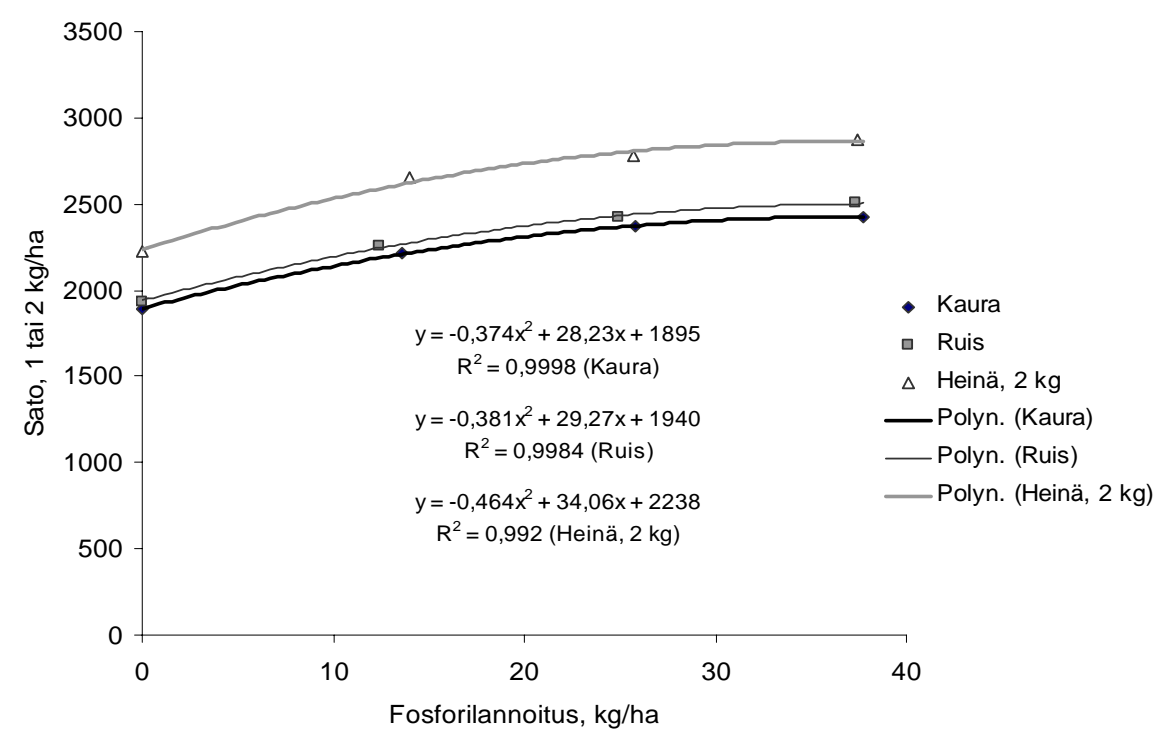

Kuva 2. P-lannoituksen satovasteita eloperäisillä mailla (ruis kaikilla maalajeilla) (Tennberg 1950). Koesatoja: heinä 37, kaura 65, syysruis 16, yksikköinä $1 \mathrm{~kg}$ viljaa ja $2 \mathrm{~kg}$ heiniä.

Eloperäisten maiden pinta pysyy keväällä pitkään kosteana ja lisätty $\mathrm{P}$ pidättyy niihin heikommin. Pienet P-määrät olivat siten suopelloilla huomattavasti tehokkaampia kuin kivennäismailla ja suurimman sadon tuottava P-lannoitus pienempi (Kuva 2). Syksyllä kosteissa oloissa orastuvalla ja varhain keväällä kasvunsa aloittavalla rukiilla P:n pintalevitys oli kivennäismailla parempi kuin kevätviljoilla. Eloperäisten maiden kauran maksimisato vastaa lannoite-P:n määrää $38 \mathrm{~kg} / \mathrm{ha}$, joka lisäsi jyväsatoa $530 \mathrm{~kg} / \mathrm{ha}$. P-lannoituksen $10 \mathrm{~kg} \mathrm{P} / \mathrm{ha}$ vaikutus oli $250 \mathrm{~kg} / \mathrm{ha}$.

Sokerijuurikkaan satokäyrät maan P-luokittain. Sokerijuurikaspelloista osa oli jo 1950-luvulla niin viljavia, että P-lannoituksen vaikutus jäi vähäiseksi (Kuva 3). P-määrien 44, 87 ja 174 kg/ha tuottamat juurisadot suurenivat jokseenkin lineaarisesti suhteessa P-määrän neliöjuureen. Joillakin koepaikoilla levitettiin superfosfaattia "talon tapaan" viisikin tonnia hehtaarille, mutta koesadot eivät suurentuneet kahden tonnin voimalla kasvaneista (Brummer 1959).

Jos optimaalisena rajatuottona pidetään 30 kiloa juurikkaita yhdellä P-kilolla, P-lannoituksen optimi oli viljavimmilla mailla $4 \mathrm{~kg} / \mathrm{ha}$, P-luokassa tyydyttävä(+) $9 \mathrm{~kg} / \mathrm{ha}$, luokassa välttävä $65 \mathrm{~kg} / \mathrm{ha}$. 
Vanhoilla lannoitteiden ja juurikkaiden hinnoilla optimit olivat suurempia ja juurikaslohkojen P-tilaa kannatti todella parantaa. Typellä ja kaliumilla jo 1950-luvulla vahvasti lannoitetulla sokerijuurikkaalla silloiset kokeet vastaavat nykyistä viljelyä suhteellisen hyvin, vaikka rivikasvit ehkä hyötyvätkin P:n sijoittamisesta enemmän kuin viljat ja öljykasvit.

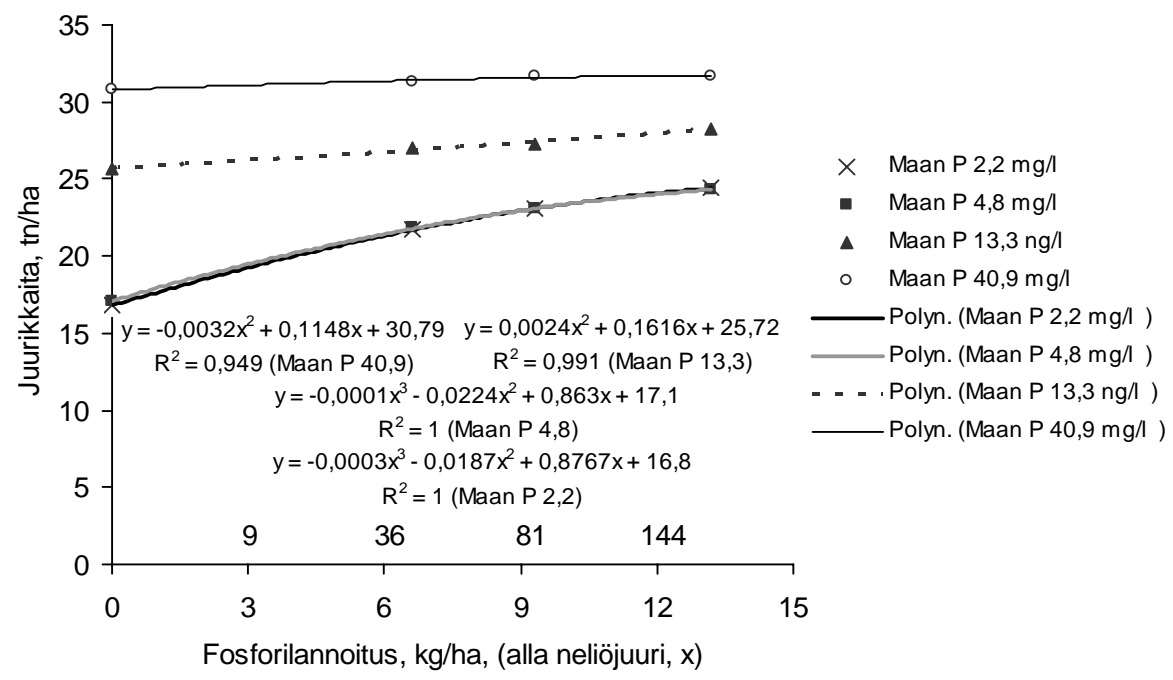

Kuva 3. P-lannoituksen vaikutus sokerijuurikkaan satoon (Brummer 1959). Maan P-luvut ovat luokkakeskiarvoja, joista 13,3 vastaa vanhaa tyydyttävää luokkaa, nykyisin vastaava keskiarvo on noin 11,5.

Portaittain nousevat P-määrät viljalla ja heinällä. Kasvinviljelyneuvojien johdolla tehdyissä paikalliskokeissa (Sippola ja Marjanen 1978) koko koealalle annetut typpi- ja kaliummäärät olivat viljalla lähellä nykyistä tasoa, mutta lannoitteiden levitys maan pintaan ja multaus äestämällä ei vastaa kylvölannoitusta vaan pikemmin lannan levitystä. Vuosittain vain keväällä typpeä saaneet ja kerran niitetyt heinäpellot poikkesivat jyrkästi nykyaikaisista säilörehunurmista. Taulukosta 1 nähdään yleisimmille viljavuusluokille laskettuja P-lannoitteen määriä, jotka tuottivat $97 \%$ :n suhteellisia satoja. Osto-P:lla näin runsas lannoitus ei ole muutamana ensimmäisenä vuonna taloudellisesti optimaalinen, mutta satokäyrät jyrkkenevät lannoituksen toistuessa vuosittain ja suurinta nettotuottoa vastaava P-määrä suurenee (Saarela ym. 1995).

Taulukko 1. Viljan ja heinän P-lannoituksen optimi ja vastaava sadonlisäys ( $\mathrm{kg} / \mathrm{ha})$ viljavuusluokittain paikallisissa lannoituskokeissa v. 1950-1976 (Sippola ja Marjanen 1978).

\begin{tabular}{|c|c|c|c|c|c|}
\hline \multirow[t]{2}{*}{ Kasvi } & \multirow[t]{2}{*}{ Maalaji } & \multicolumn{2}{|c|}{ Maan P-luokka välttävä } & \multicolumn{2}{|c|}{ Maan P-luokka tyydyttävä } \\
\hline & & P kg/ha & Sadonlisä & P kg/ha & Sadonlisä \\
\hline \multirow[t]{3}{*}{ Viljat } & Eloperäiset maat & 64 & 510 & 35 & 220 \\
\hline & Karkeat kiv.maat & 42 & 300 & 21 & 160 \\
\hline & Savimaat & 40 & 260 & 26 & 120 \\
\hline \multirow[t]{3}{*}{ Heinät } & Eloperäiset maat & 34 & 750 & 44 & 600 \\
\hline & Karkeat kiv.maat & 32 & 350 & 27 & 240 \\
\hline & Savimaat & 42 & 550 & 23 & 250 \\
\hline
\end{tabular}

Vuosien 1931-1954 P-lannoituksen porraskokeet. Tutkimuksen 33 kokeesta vanhimmat perustettiin vuonna 1931. Kivennäismailla tehtiin 11 koetta ja kolmeen ryhmään jaetuilla turvemailla 22 koetta (kuva 4). Koesatoja kertyi kaikkiaan 275 eli runsaat kahdeksan koepaikka kohti. Luontaisesti niukkaravinteisilla turpeilla pienet $\mathrm{P}$-määrät olivat tehokkaita ja pari kertaa toistettuna $32 \mathrm{kiloa} \mathrm{P} / \mathrm{ha} / \mathrm{v}$ tuotti yhtä runsaita satoja kuin $48 \mathrm{~kg} / \mathrm{ha} / \mathrm{v}$. Kivennäismailla käytetyt pienemmät P-määrät eivät sen sijaan riittäneet kaikilla koepaikoilla täyteen satoon, vaikka P-lannoituksen vaikutus oli pienempi. Kivennäismaiden satoyhtälön derivaatan arvo on 10 P-lannoituksella $10,6 \mathrm{~kg} / \mathrm{ha}$. Vaikka sato suureni, runsas P-lannoitus ei ollut nykyisillä hintasuhteilla kannattavaa. P-lannoitus suurensi ruokinnan kannalta tärkeänä pidettyä heinän P-pitoisuuden laihoilla turvemailla moninkertaiseksi. 


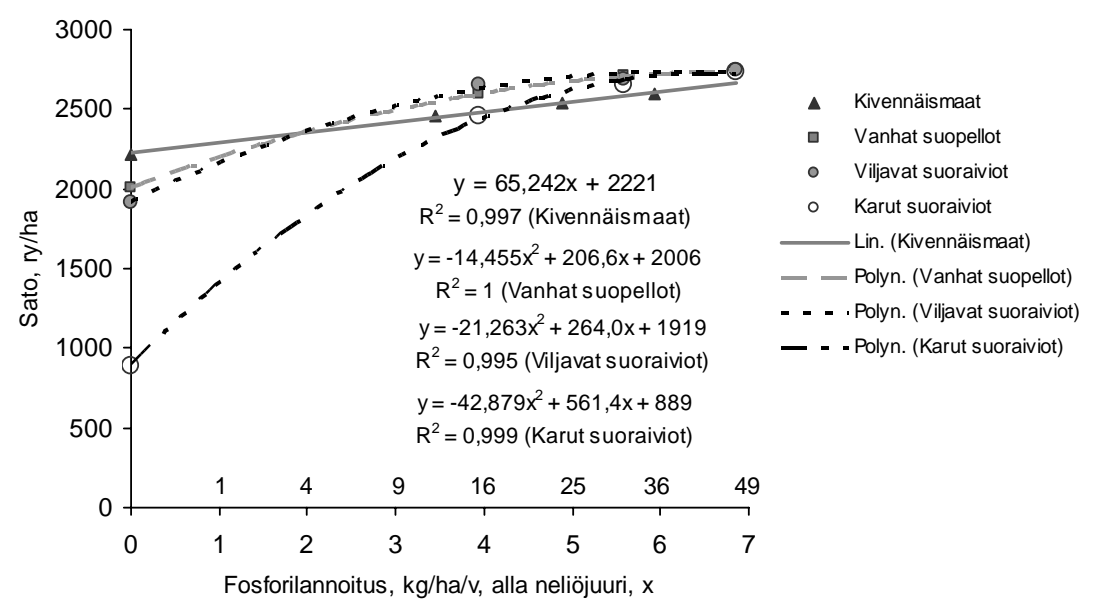

Kuva 4. P-lannoituksen vaikutus pitkäaikaisissa kenttäkokeissa enimmäkseen heinästä ja kaurasta koostuvaan rehuyksikkösatoon (Salonen ja Tainio 1957, p. 78).

Monivuotiset kenttäkokeet niukkafosforisilla turve- ja savimailla. Viljelyssä hajoavan turpeen kivennäiset huuhtoutuvat pois, siirtyvät kasviin tai rikastuvat pienenevään maamäärään, mutta polttoturpeen jättöalueelle turpeesta ei jää ravinteita. Teorian mukaisesti niukkaravinteisella suonpohjalla Tohmajärven Valkeasuolla viljeltiin timoteita säilörehuksi kahdella typpi- $(\mathrm{N})$ lannoituksen tasolla (Virkajärvi ja Huhta 1993). Toisella nurmikierrolla v. 1985-1989 ensimmäistä puolta pienemmillä P-määrillä saatuja kuiva-ainesatoja esitetään kuvassa 5.

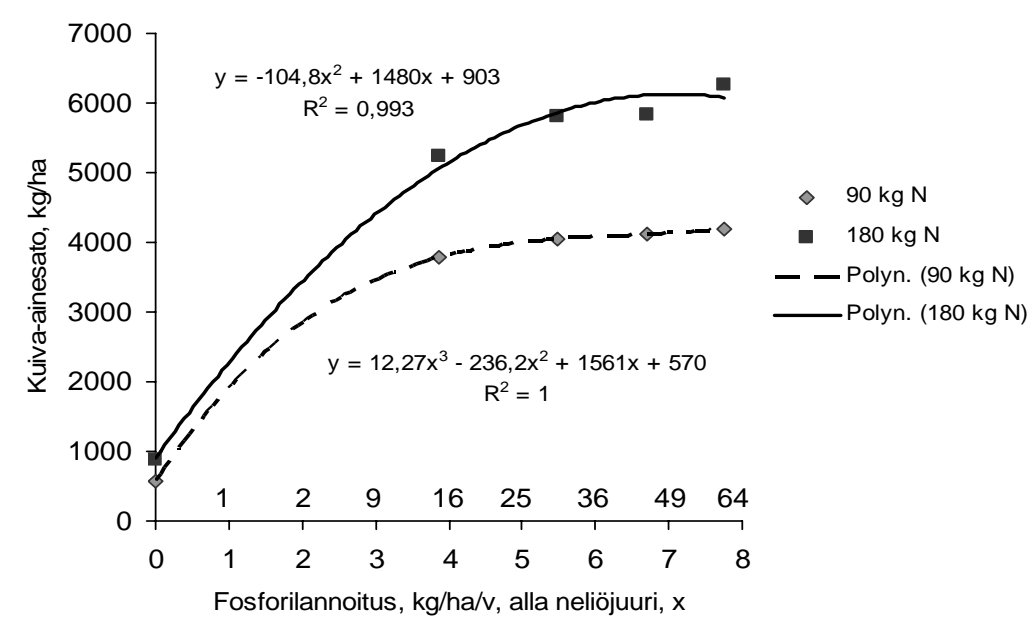

Kuva 5. P-lannoituksen vaikutus timoteisäilörehunurmen kuiva-ainesatoon polttoturvesuon jättöalueella Tohmajärven Valkeasuolla v. 1985-1989 (Virkajärvi ja Huhta 1993).

Timotein P:n otto oli N-lannoituksella $90 \mathrm{~kg} 0,5-12,5 \mathrm{~kg}$ ja $180 \mathrm{~N}-\mathrm{kg}: 1 \mathrm{la} 0,7-22,2 \mathrm{~kg} / \mathrm{ha}$. N-määrällä $90 \mathrm{~kg} / \mathrm{ha} / \mathrm{v}$ sadon valkuaispitoisuus oli n. 7,0\% eli ruokinnan kannalta kovin matala. N-tasoa 150 $\mathrm{kg} / \mathrm{ha} / \mathrm{v}$ vastaava P-lannoituksen optimi on interpoloimalla arvioituna noin $28 \mathrm{~kg} / \mathrm{ha}$. Tällä Nlannoituksella P-taseen ylijäämää oli jaksolla $1985-1989$ noin $11 \mathrm{~kg} / \mathrm{ha} / \mathrm{v}$ ja 1980-1789 yhteensä yli $200 \mathrm{~kg} / \mathrm{ha}$ sekä maan P-luku $8,2 \mathrm{mg} / 1$ eli luokan tyydyttävä alapäätä vastaava. Levitettäessä P:a vain alussa $25 \mathrm{~kg} / \mathrm{ha}$ P-luku oli toisella jaksolla $0,7-0,9 \mathrm{mg} / 1 \mathrm{ja} \mathrm{pH} \mathrm{5,5-5,3.} \mathrm{Ympäristötukeen} \mathrm{oikeuttava}$ vuotuinen P-lannoitus oli $16 \mathrm{~kg} / \mathrm{ha}$ eli huomattavasti satokäyrän mukaista tarvetta pienempi. V. 1993 hinnoilla 30 ja $60 \mathrm{~kg} \mathrm{P} /$ ha olivat N-tasolla $180 \mathrm{~kg} /$ ha yhtä kannattavia (Virkajärvi ja Huhta 1993).

Lannoituksen P-määrän vaikutus niukkafosforisella savimaalla. Pitkään viljelemättä olleen runsasmultaisen saven monta vuotta kestänyt erinomainen mururakenne helpotti ravinteiden saantia ja suurensi viljasatoja (Kuva 6). Aitosavimaassa oraiden juuret eivät kuitenkaan tavoittaneen sijoitettua lannoitetta kunnolla kuivina kausina. Keskikesän sadekausina P:n sijoittaminen kapeilla vantailla 
niukkafosforiseen maahan ja lannoiteriveihin kasvanut tiheä juuritupas, joka todennäköisesti kulutti runsaasti happea, näytti korostavan myös liian veden vahingollisuutta.

Näissä oloissa peruslannoitus oli odottamatta aivan yhtä tehokas menetelmä P-kiloa kohti kuin kylvölannoitus. Suurin ympäristötukeen oikeuttava P-määrä oli viitenä ensimmäisenä vuonna keskimäärin $33 \mathrm{~kg} / \mathrm{ha}$ ja kolmena viimeisenä P-luokan muututtua $27 \mathrm{~kg} / \mathrm{ha}$. Tässä kohdalla satokäyrän kulmakerroin oli $15 \mathrm{~kg}$ viljaa/P-kg. 1990-luvun alun hintasuhteilla optimilannoitus oli noin $50 \mathrm{~kg} / \mathrm{ha}$.

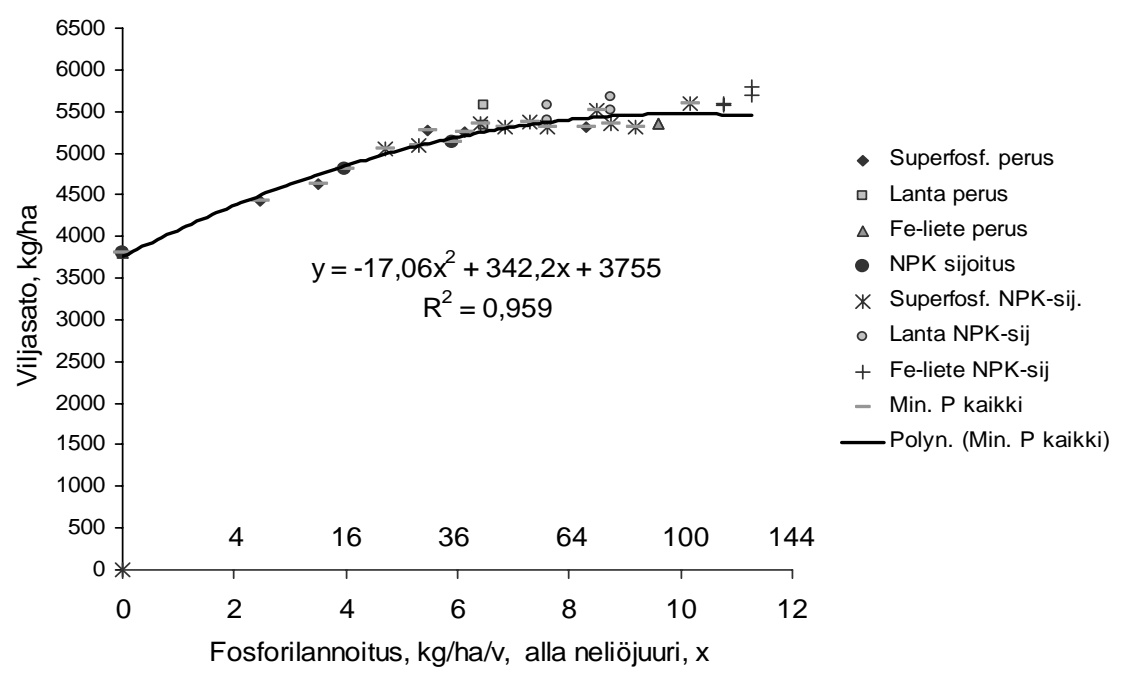

Kuva 6. 8-vuotisen kokeen alussa ja 3. v. levitetyn (pienin määrä vain alussa, suurin myös 4. v.) peruslannoituksen ja vuosittain sijoitetun lannoite-P:n vaikutus viljasatoon Jokioisten savimaalla. Maan P-luku vaihteli 6. v. syksyllä välillä 0,7 ja $5,9 \mathrm{mg} / 1$.

Monivuotiset P-lannoituskokeet v. 1977-1994. Erityisesti suunnitellun 10 vuoden jakson jälkeen tutkimuksen tavoitteena oli selvittää kuinka sadot muuttuvat eri P-lannoitustasoilla suhteessa maan Ptilaan. Vuosittain toistetun lannoituksen ja koeajan vaikutus oli suuri ja optimaalinen P-määrä kasvoi (Saarela ym. 1995). Kuvissa 7 ja 8 esitetään tuloksia koevuosilta 5-18, jotka vastaavat pitkän ajan vaikutuksia paremmin kuin koko koejakso. Kuvassa 7 on satokäyriä neljältä hietamaalla. Kokeiden 18261 ja 43327 satojen kääntyminen laskuun suurilla P-määrillä johtui ohran haitallisesta, aikaisesta lakoontumisesta. Nykyiset lajikkeet hyötynevät tällaisissa oloissa lannoituksesta paremmin. Satoja hyvin vastaavat polynomi-yhtälöt määrittävät P-lannoituksen vaikutuksen tarkasti välillä $0-60 \mathrm{~kg} / \mathrm{ha}$.

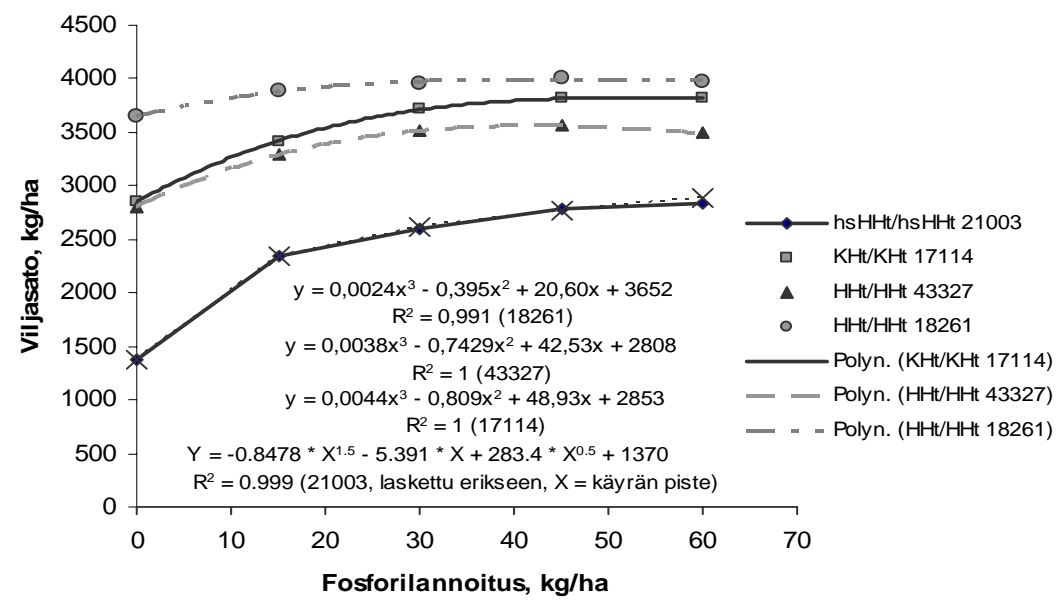

Kuva 7. P-lannoituksen vaikutus viljasatoon neljällä hietamaalla.

Kuvassa 8 esitetään 193 koesadosta laskettu yhteenveto P-määrän vaikutuksesta viljasatoon. Tavoitteen ollessa sadon maksimointi, suhteellisen viljaviakin maita lannoitettaisiin suurehkoilla Pmäärillä. Nykyisiä hintasuhteita vastaava tehokkuus, 10-15 kiloa viljaa yhdellä P-kilolla, rajoittaa paitsi optimaalista lannoitusta myös sadon määrää. Lannan käyttö voi olla kannattavaa ja 
tarkoituksenmukaista, vaikka sadonlisäys olisi $5 \mathrm{~kg} / \mathrm{P}-\mathrm{kg}$. Yksittäisiä koepaikkoja oli niin vähän, että satokäyrien välit eivät ole tasaisia, kuten varmaan suurissa aineistoissa. Luokkien erot ovat kuitenkin niin suuria, että tyydyttävän ja välttävän luokan puolittaminen näyttää perustellulta.

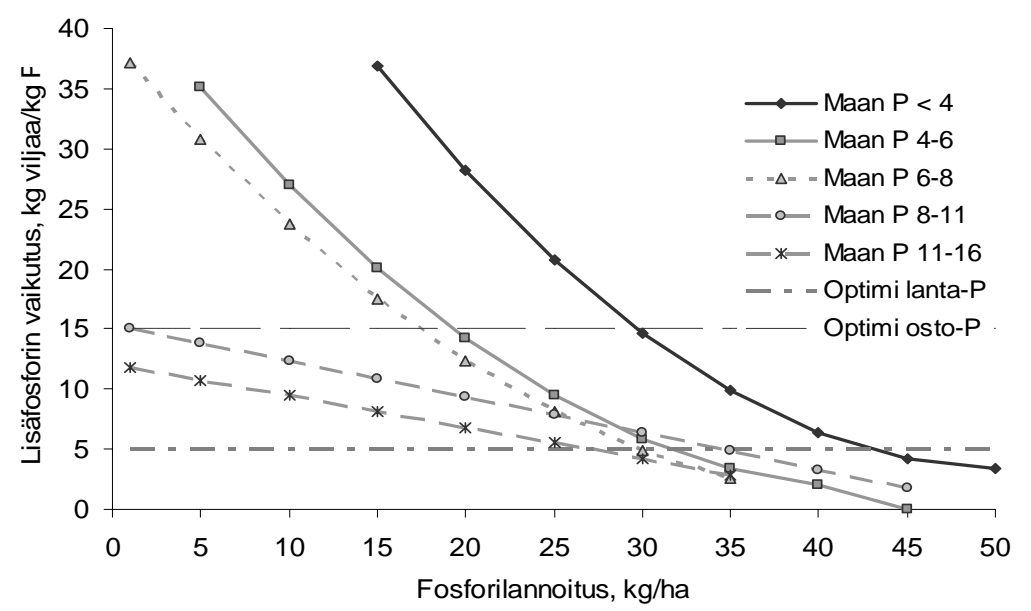

Kuva 8. P-lannoituksen määrän vaikutus viljasatoon puolitetuissa maan P-luokissa

\section{Johtopäätökset}

Usean rinnakkain samalla pellolla käytetyn P-määrän tuottamista sadoista lasketut käyrät osoittivat hyvin P-lannoituksen vaikutusta. Satovastekäyristä voidaan johtaa lannoituksen rajatuotot eri Pmäärillä ja niiden mukaiset optimit erilaisilla tuotteiden ja lannoitteiden hintasuhteilla. Esitettyjen satokäyrien ja aikaisempien tutkimusten mukaan ympäristötukeen oikeuttavat P-määrät ovat maatalouden kannalta riittäviä ja pitkänäkin aikana taloudellisia P-tilaltaan hyvillä mailla.

P-tilaltaan huonommilla mailla tyydyttävän luokan alapäässä alkaen ympäristötukeen oikeuttavat P-määrät ovat sen sijaan arveluttavan pieniä hyvää, tuottavaa viljelyä varten. Lyhyenä aikana taloudellisia menetyksiä aiheutuu lähinnä lannan käytön vaikeutumisesta, ja sadonmenetykset kasvavat vähitellen.

\section{Kirjallisuutta}

Brummer, V. 1959. Lannoituksen vaikutuksesta sokerijuurikkaan satoon. Acta Agralia Fennica 94: 201-236.

Munk, H. \& Rex, M. 1990. Zu Eichung von Bodenuntersuhcungsmethoden auf Phosphat. Agroibiological Research 43: 164-174.

Munk. H., Heyn, J. \& Rex, M. 2005. Vergleichende Berachtung von Verfahren zur Auswertung von Nährstoffsteigerungsversuchen am Beispiel Phosphor. Journal of Plant Nutrition and Soil Science 168: 789-796.

Saarela, I. \& Sippola, J. 1990. Inorganic leaf phosphorus and soil tests as indicators of phosphorus nutrition in cereals. Communications in Soil Science and Plant Nutrition 21: 1927-1943.

Saarela, I., Järvi, A., Hakkola, H. \& Rinne, K. 1995. Fosforilannoituksen porraskokeet 1977-1994. Maatalouden tutkimuskeskus, Tiedote 16/95. 94 p. + app.

Saarela, I, Salo, Y. \& Vuorinen, M. 2006a. Effects of repeated phosphorus fertilisation on field crops in Finland. 1. Yield responses on clay and loam soils in relation to soil test $\mathrm{P}$ values. Agricultural and Food Science 15: $106-123$.

Saarela, I. Huhta, H. \& Virkajärvi, P. 2006b. Effect of repeated phosphorus fertilisaton on field crops in Finland. 2. Sufficient application rates on silty and sandy soils. Agricultural and Food Science 15: 423-443.

Salonen, M. \& Tainio, A. 1957. Fosforilannoitusta koskevia tutkimuksia. Selostus kiinteillä kentillä vuosina 1931-54 suoritetuista lisättyjen fosforimäärien kokeista. Valtion maatalouskoetoiminnan julkaisuja $164.104 \mathrm{p}$ Sippola, J. \& Marjanen, H. 1978. Viljavuusluokittaiset sadonlisäykset paikallisissa nousevien fosfori- ja kaliummäärien kokeissa. 16 p. Maatalouden tutkimuskeskus, Maantutkimuslaitos, Tiedote 3. 16 p.

Tennberg, F. 1950. Tuloksia fosfaattilannoitteen nousevien määrien kokeista. Maatalous ja

Koetoiminta 4: 200-210.

Virkajärvi, P. \& Huhta, H. 1993. Nurmen viljely polttoturvesoiden jättöalueilla. Timoteinurmen fosforilannoitus Tohmajärven Valkeasuolla. Maatalouden tutkimuskeskus, Tiedote 7/93. 27 p. +app. 